\title{
Ultrasonically Surface-Activated Nickel Foam as a Highly Efficient Monolith Electrode for the Catalytic Oxidation of
}

\section{Methanol-to-Formate}

Muhammad Imran Abdullah*1, Asima Hameed ${ }^{1}$, Ning Zhang ${ }^{2}$, Md Hujjatul Islam ${ }^{3}$, Mingming $\mathrm{Ma}^{* 1}$ and Bruno G. Pollet*3

1 CAS Key Laboratory of Soft Matter Chemistry, Hefei National Laboratory for Physical Sciences at the Microscale, University of Science and Technology of China, Hefei, Anhui 230026, China

E-mail: mma@ustc.edu.cn; mimran@mail.ustc.cn

2 Department of Biology and Environmental Engineering, Hefei University, Hefei, Anhui 230022, China

3 Hydrogen Energy and Sonochemistry Research group, Department of Energy and Process Engineering, Norwegian University of Science and Technology (NTNU), NO-7491, Trondheim, Norway

E-mail: bruno.g.pollet@,ntnu.no 


\section{Contents}

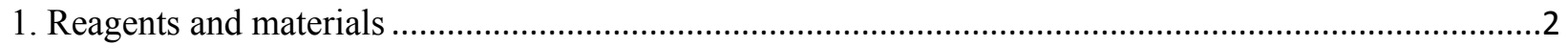

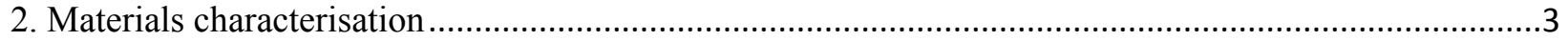

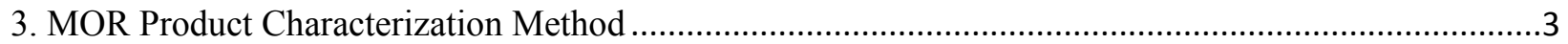

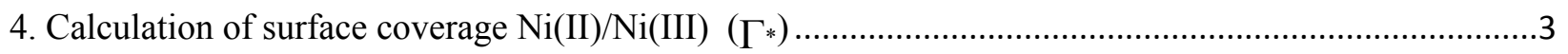

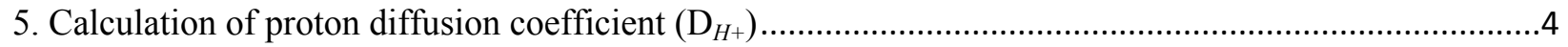

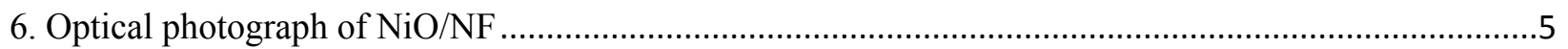

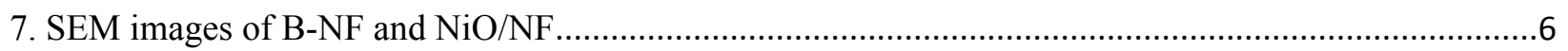

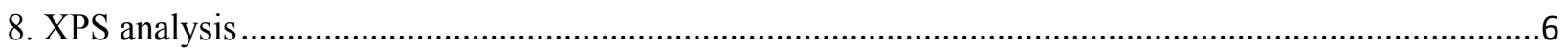

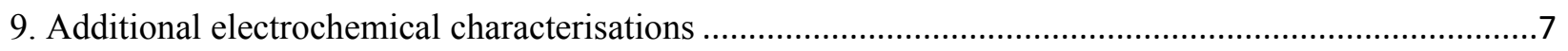

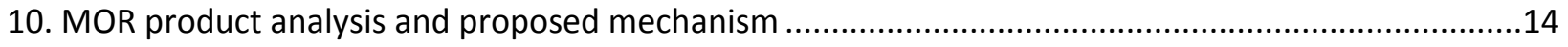

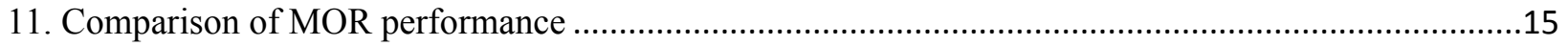




\section{Reagents and materials}

The potassium hydroxide $(\mathrm{KOH})(95 \%)$ and methanol $\left(\mathrm{CH}_{3} \mathrm{OH}\right)(99.9 \%)$ were used. All chemicals were purchased from Sinopharm Chemical Reagent Co. Ltd and were of analytical grade. Deionised (DI) water was used to prepare all solutions. All reagents and chemicals were used without further purification.

\section{Materials characterisation}

The $\mathrm{Cu} \mathrm{K} \alpha(\lambda=1.54178 \AA)$ radiation and Rigaku-D X-ray diffractometer were used to performed powder diffraction X-ray experiments. The Thermos ESCALAB 250 with Al $\mathrm{K} \alpha(\gamma=1486.6 \mathrm{eV})$ was used as an exciting radiation source to record the X-ray photoelectron spectra (XPS). The SEM images were taken by field emission scanning electron microscope (FE-SEM, JEOL JSM6700F). The LABRAM-HR Raman system was used to record Raman spectra. All samples were dried under before characterisation.

\section{MOR Product Characterization Method}

The liquid products were analyzed by nuclear magnetic resonance (NMR) spectrometer and ion chromatograph. ${ }^{13} \mathrm{C}$ NMR spectra were recorded on a Bruker -500 NMR. In which, $1 \mathrm{~mL}$ electrolyte was added to $0.2 \mathrm{~mL} \mathrm{D}_{2} \mathrm{O}$ and maleic acid was used as an internal standard. The ion chromatograph (ICS-2500, DIONEX) was used with the eluent of $0.1 \mathrm{M} \mathrm{NaOH}$.

\section{Calculation of surface coverage $\mathrm{Ni}(\mathrm{II}) / \mathrm{Ni}(\mathrm{III})\left(\Gamma^{*}\right)$}

The surface coverage of $\mathrm{Ni}(\mathrm{II}) / \mathrm{Ni}(\mathrm{III})$ redox species in the $\mathrm{B}-\mathrm{NF}$ and $\mathrm{NiO} / \mathrm{NF}$ electrode was studied based upon the linear relationship between the peak current density values of the $\mathrm{Ni}(\mathrm{II}) / \mathrm{Ni}(\mathrm{III})$ redox couple and the scan rate using cyclic voltammetry measurement. The cyclic 
voltammograms of the $\mathrm{NiO} / \mathrm{NF}$ and $\mathrm{B}-\mathrm{NF}$ electrodes in $1.0 \mathrm{M} \mathrm{KOH}$ solution at different scan rates from 5 to $100 \mathrm{mV} \cdot \mathrm{s}^{-1}$ were performed. The anodic and the cathodic peak current densities increased with increased scan rate. However, due to the limitation of the reaction kinetics, the time for the complete formation of $\mathrm{Ni}(\mathrm{III})$ was insufficient at higher scan rates ${ }^{1}$. Thus, the peak potentials displayed a hysteresis effect. It is clear that the peak current densities of the $\mathrm{Ni}(\mathrm{II}) / \mathrm{Ni}(\mathrm{III})$ redox couple are linearly proportional to the scan rate. As a result, the surface coverage of the $\mathrm{Ni}(\mathrm{II}) / \mathrm{Ni}(\mathrm{III})$ redox species in the $\mathrm{B}-\mathrm{NF}$ and $\mathrm{NiO} / \mathrm{NF}$ electrode can be obtained based upon the following equation $2^{2}$.

$I_{P}=\left(\frac{z^{2} F^{2}}{4 R T}\right) A \Gamma^{*} v$

where $I_{\mathrm{p}}, \mathrm{z}, R, T, A, v$, and $\Gamma *$ are the peak current density, the number of transferred electrons, the general gas constant, the temperature, the apparent area of electrode, the potential scan rate, and the surface coverage of the redox species, respectively. The value of $\Gamma^{*}$ for $\mathrm{NiO} / \mathrm{NF}$ electrode was calculated according to the average of the anodic and the cathodic results were found to be $\mathbf{6 . 3 3} \mathbf{x}$ $10^{-7} \mathbf{m o l} \cdot \mathbf{c m}^{-2}$

\section{Calculation of proton diffusion coefficient $\left(\mathrm{D}_{\mathrm{H}^{+}}\right)$}

A good linear dependence of the anodic and the cathodic peak current density of the NiO/NF electrode with the square root of the scan rate was observed, suggesting that the total redox transition of $\mathrm{Ni}(\mathrm{II})$ was a diffusion-controlled process, a finding which is in good agreement with previous studies in the literature ${ }^{3}$. It was reported that the $\mathrm{Ni}(\mathrm{II}) / \mathrm{Ni}(\mathrm{III})$ redox process is controlled by the solid-phase body of the proton diffusion ${ }^{3}$. Therefore, the diffusion coefficient $\left(\boldsymbol{D}_{\boldsymbol{H}^{+}}\right)$of the rate-limiting proton is an important parameter for the characterisation of the oxidation behaviour of the electrocatalysts. The value of $\boldsymbol{D}_{\boldsymbol{H}^{+}}$at $298 \mathrm{~K}$ can be estimated using equation $3^{2}$. 
$I_{P}=2.69 \times 10^{5} z^{\frac{3}{2}} A D^{\frac{1}{2}} C v^{\frac{1}{2}}$

where $I_{p}, z, A, D, C$, and $v$ are the anodic peak current, the number of transferred electrons, the apparent area of the electrode, the proton diffusion coefficient, the proton concentration, and the potential scan rate, respectively. The proton concentration in the nickel hydroxide $\left(\mathrm{Ni}(\mathrm{OH})_{2}\right.$ is assumed to be the same as that of $\mathrm{Ni}(\mathrm{II})$ based on the stoichiometry of reaction in the following

$$
\mathrm{Ni}(\mathrm{OH})_{2} \rightarrow \mathrm{NiOOH}+\mathrm{H}^{+}+\mathrm{e}^{-}
$$

The concentration of $\mathrm{Ni}$ (II) was estimated to be $0.048 \mathrm{~mol} \cdot \mathrm{cm}^{-3}{ }^{4}$ Thus, the $\boldsymbol{D}_{\boldsymbol{H}^{+}}$was found to be $4.5 \times 10^{-7} \mathrm{~cm}^{2} \cdot \mathrm{s}^{-1}$ for $\mathrm{NiO} / \mathrm{NF}$ electrode.

\section{Optical photograph of $\mathrm{NiO} / \mathrm{NF}$}

The Nickel foam was obtained from Cyber Electrochemical Material (Volume: $1.0 \mathrm{~mm} * 200 \mathrm{~mm} * 250 \mathrm{~mm}$ Area Density: $350 \mathrm{~g} / \mathrm{m}^{3}$, PPI 110, Pore Size: $0.1 \mathrm{~mm}$, Porosity: $97.2 \%$.
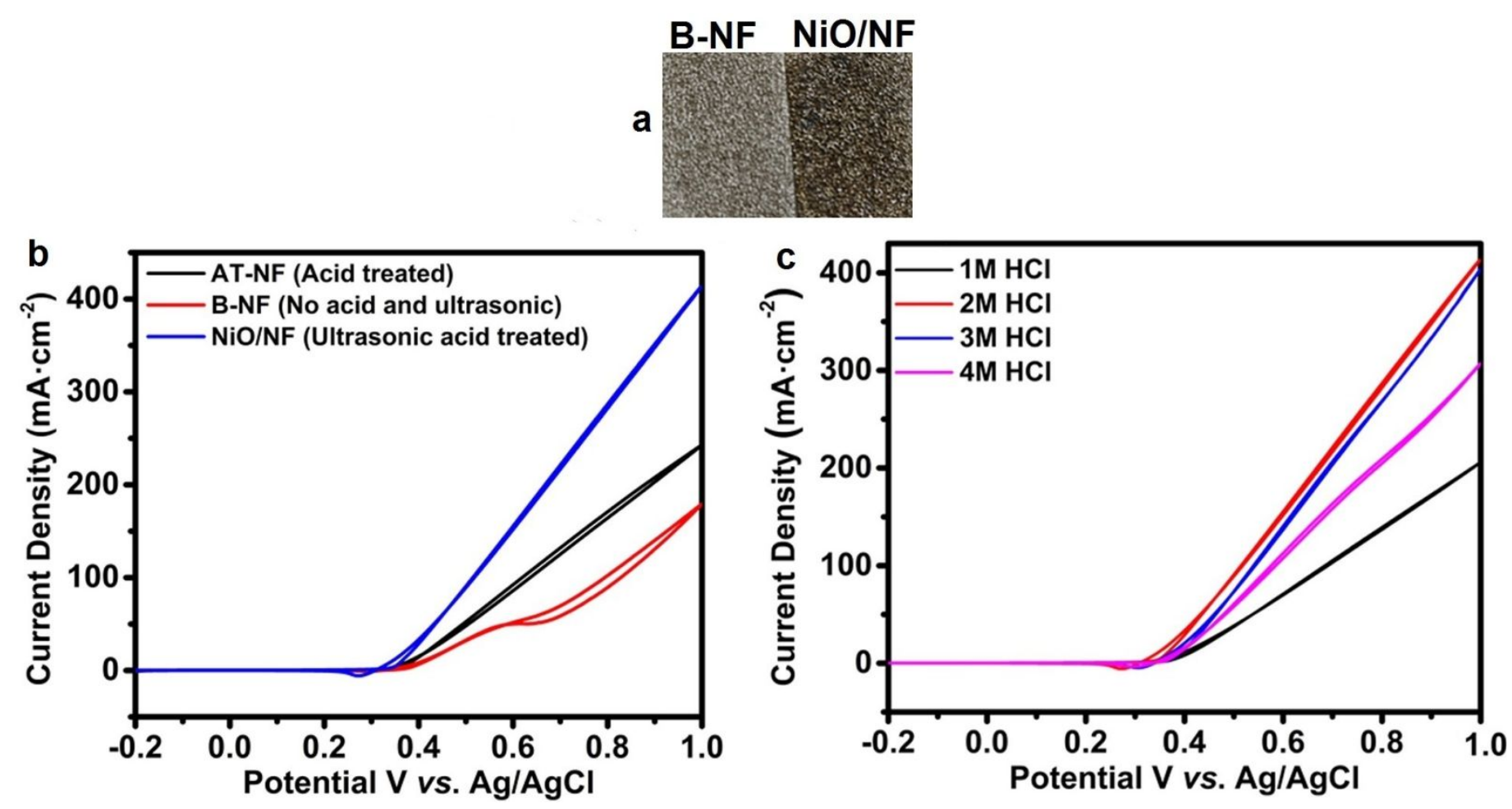
Figure S1. a) Photograph of bare nickel foam B-NF and NiO/NF b) Effect of acid and ultrasonication on MOR performance c) Effect of $\mathrm{HCl}$ concentrations on MOR performance.

\section{SEM images of $\mathrm{B}-\mathrm{NF}$ and $\mathrm{NiO} / \mathrm{NF}$}

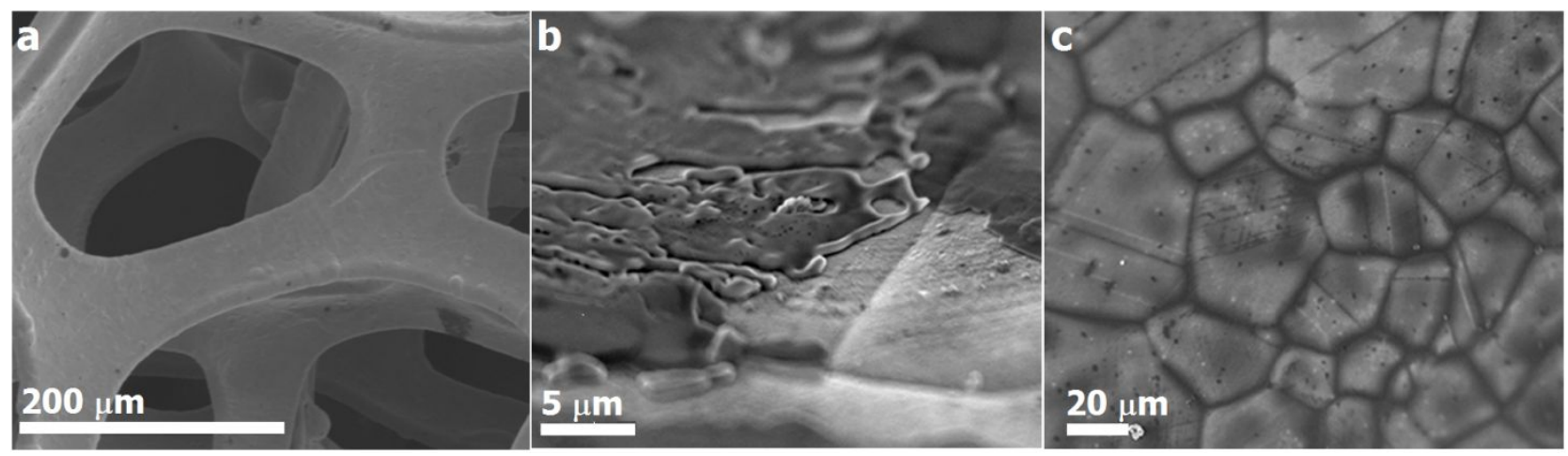

Figure S2. (a) SEM images of B-NF (b,c) SEM images of NiO/NF after long-term MOR.

\section{XPS analysis}

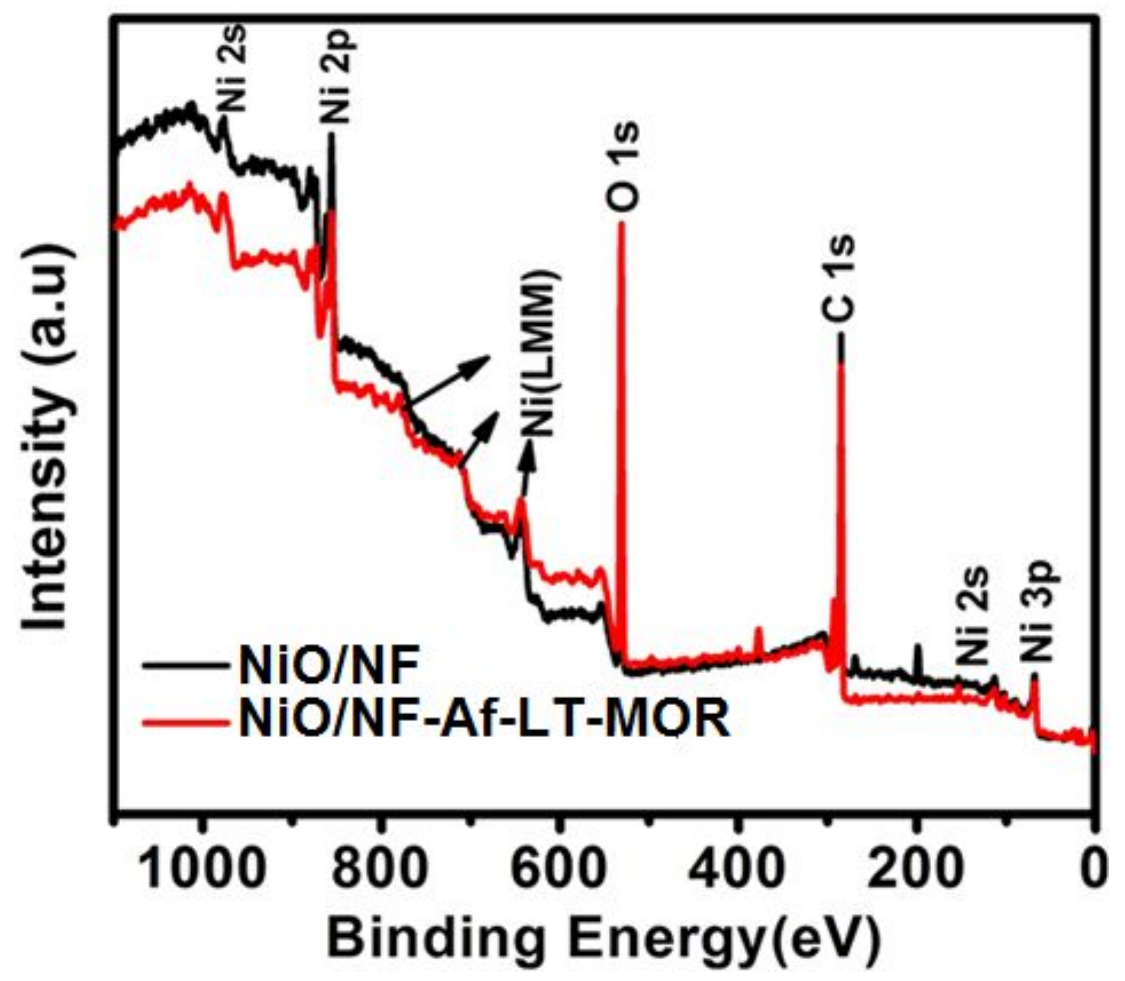

Figure S3. XPS survey spectrum for NiO/NF before and after long-term MOR performance 
9. Additional electrochemical characterisations
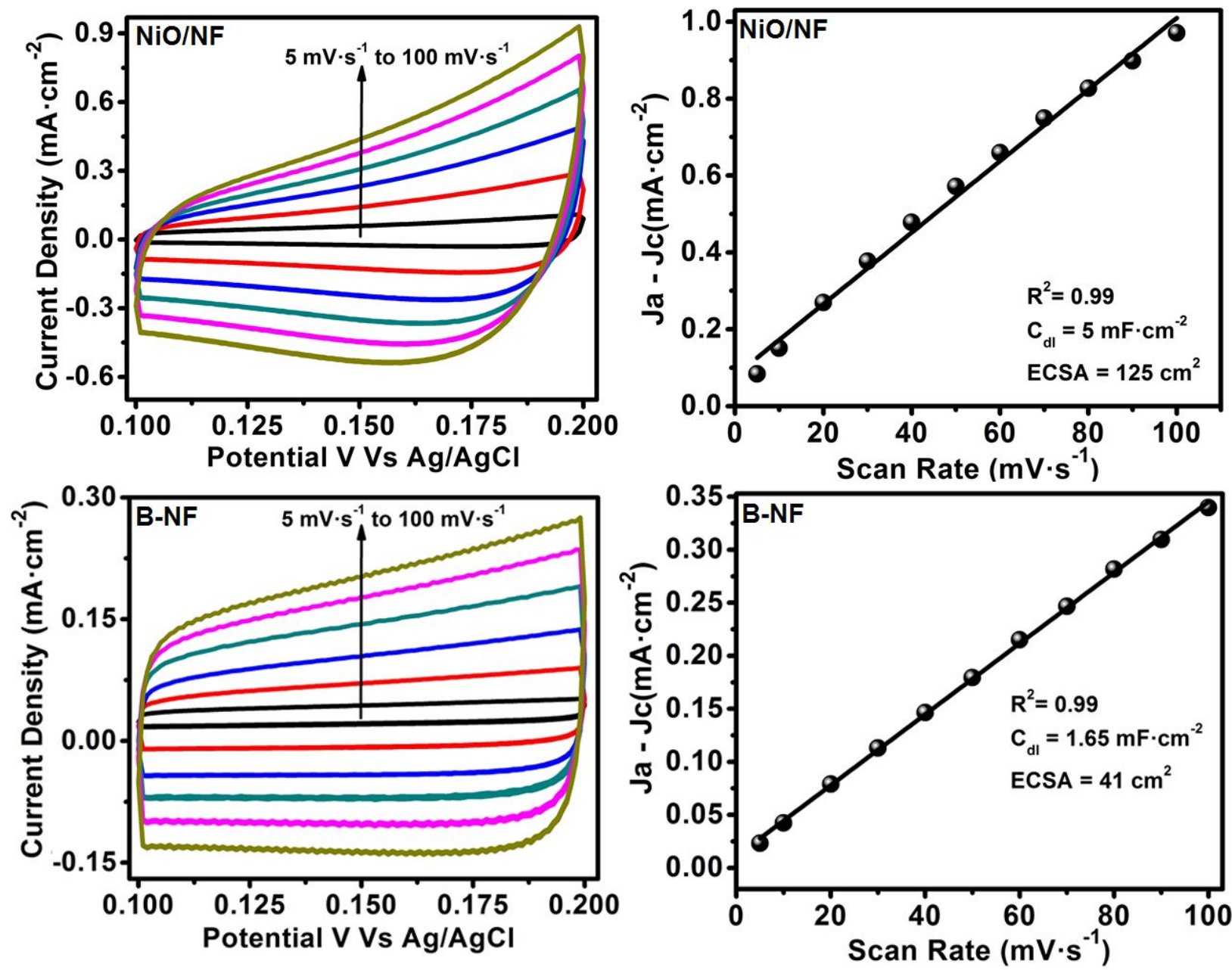

Figure S4. (a, b) Cyclic voltammograms in $1.0 \mathrm{M} \mathrm{KOH}$ solution measured in the non-Faradaic potential range of $+0.10 \mathrm{~V}$ to $+0.20 \mathrm{~V}$ vs. $\mathrm{Ag} / \mathrm{AgCl}$ at scan rates of 5 to $100 \mathrm{mV} \mathrm{s}^{-1}$ for $\mathrm{NiO} / \mathrm{NF}$ and B-NF respectively. (c, d) Charging current density differences $(\Delta j=j \mathrm{a}-j \mathrm{c})$ plotted against scan rate for $\mathrm{NiO} / \mathrm{NF}$ and $\mathrm{B}-\mathrm{NF}$, respectively.

This ECSA parameter should be more precise for describing the surface change of NF based MOR and OER electrodes. Cyclic voltammetry $(\mathrm{CV})$ measurements were carried out in $1.0 \mathrm{M} \mathrm{KOH}$ to probe the electrochemical double layer capacitance $\left(C_{\mathrm{dl}}\right)$ of $\mathrm{B}-\mathrm{NF}$ and $\mathrm{NiO} / \mathrm{NF}$ at non-faradaic 
overpotentials as a means for determining ECSAs. A series of CV measurements were performed at various scan rates $\left(v: 5,10,20,50,100\right.$ and $\left.200 \mathrm{mV} \mathrm{s}^{-1}\right)$ between $+0.10 \mathrm{~V}$ and $+0.20 \mathrm{~V} v s$. $\mathrm{Ag} / \mathrm{AgCl}$. The double layer capacitance $\left(C_{\mathrm{dl}}\right)$ was estimated by plotting the $j=(j \mathrm{a}-j \mathrm{c})$ at $+0.15 \mathrm{~V}$ vs. $\mathrm{Ag} / \mathrm{AgCl}$ versus scan rate. The linear slope was found to be twice of the double layer capacitance $C_{\mathrm{dl}}$. For the determination of the ECSA, a specific capacitance $\left(C_{\mathrm{s}}\right)$ value of $C \mathrm{~s}=0.040$ $\mathrm{mF} \mathrm{cm}^{-2}$ in $1.0 \mathrm{M} \mathrm{KOH}$ solution was used from previous reports. The ECSAs of the various electrodes was calculated according to the following equation (1).

$$
\mathrm{ECSA}=C_{\mathrm{dl}} / C \mathrm{~s}
$$

Figure S4a and Figure S4c show the cyclic voltammograms in 1.0 M KOH solution of NiO/NF and $\mathrm{B}-\mathrm{NF}$ measured in the non-Faradaic potential range of $+0.10 \mathrm{~V}$ to $+0.20 \mathrm{~V}$ vs. $\mathrm{Ag} / \mathrm{AgCl}$ at scan rates of $5,10,20,50,100,200 \mathrm{mV} \mathrm{s}^{-1}$, respectively. The corresponding charging current density differences $(\Delta j=j \mathrm{a}-j \mathrm{c})$ plotted against scan rate are shown in Figure S4b and Figure S4d, where the double layer capacitances $C_{\mathrm{dl}}$ are obtained, equal to half the value of the slope. Therefore, the ECSA values of these electrodes can be calculated using equation (1), which were found to be $41 \mathrm{~cm}^{2}$ (B-NF) and $125 \mathrm{~cm}^{2}(\mathrm{NiO} / \mathrm{NF})$, respectively. It is evident that the ECSAs of NF after acid treatment are larger than that those found for B-NF. Therefore, the intrinsic activity of in-situ formed layer plays a dominant role in the MOR activity enhancement for NF after acid treatment. 
Table S1. Redox parameters for the selected electrocatalysts in $1.0 \mathrm{M} \mathrm{KOH}$ solution ${ }^{\mathrm{a}}$ ${ }^{\text {a The }} \mathrm{CVs}$ of NiO/NF exhibited two cathodic and anodic peaks. The $j_{\mathrm{p}, \mathrm{a}}, j_{\mathrm{p}, \mathrm{c}}, E_{\mathrm{p}, \mathrm{a}}, E_{\mathrm{p}, \mathrm{c}}$ and $\Delta E$

\begin{tabular}{|c|c|c|c|c|c|c|c|c|}
\hline Catalyst & $\begin{array}{c}\dot{L}_{\mathrm{pa}} \\
(\mathrm{mA})\end{array}$ & $\begin{array}{c}E_{\mathrm{pa}} \\
(\mathrm{V} v s . \mathrm{RHE})\end{array}$ & $\begin{array}{c}j_{\mathrm{pc}} \\
(\mathrm{mA})\end{array}$ & $\begin{array}{l}E_{\mathrm{pc}} \\
(\mathrm{V} v s . \mathrm{RHE})\end{array}$ & $\Delta E_{\mathrm{p}}(\mathrm{V})$ & $\begin{array}{c}\Gamma^{*} \\
\mathrm{~mol} \cdot \mathrm{cm}^{-2} \\
\left(\mathrm{x} 10^{-7}\right)\end{array}$ & $\begin{array}{c}D \\
\mathrm{~cm}^{2} \cdot \mathrm{s}^{-1} \\
\left(\mathrm{x} 10^{-7}\right)\end{array}$ & [Ref] \\
\hline Ni-NPs & 3.33 & 1.46 & -1.22 & 1.34 & 0.11 & 1.93 & 0.319 & 5 \\
\hline $\mathrm{Ni}_{3} \mathrm{C}$ & 5.38 & 1.40 & -3.58 & 1.30 & 0.13 & 1.93 & 0.0599 & 6 \\
\hline $\mathrm{Ni}-\mathrm{Co}-\mathrm{Se}$ & 8.43 & 1.38 & -5.57 & 1.29 & 0.10 & 1.40 & 0.128 & 7 \\
\hline $\mathrm{Ni}$-Se & 10.8 & 1.44 & -6.9 & 1.31 & 0.14 & 2.1 & 0.0002 & 4 \\
\hline $\mathbf{N i}_{97} \mathbf{B i}_{3}$ & 29 & 1.39 & -19.0 & 1.27 & 0.12 & 3.97 & 2 & 8 \\
\hline Ni-Co-P & 4.40 & 1.38 & -2.39 & 1.25 & 0.13 & - & - & 9 \\
\hline B-NF & 11 & 1.48 & -8.08 & 1.31 & 0.17 & 1.52 & 0.244 & This work \\
\hline $\mathrm{NiO} / \mathrm{NF}$ & 50.0 & 1.44 & -42.0 & 1.24 & 0.20 & 6.33 & 4.5 & This work \\
\hline
\end{tabular}
values were extracted from the CVs (performed in $1.0 \mathrm{M} \mathrm{KOH}$ at $50 \mathrm{mV} \mathrm{s}^{-1}$ ). 


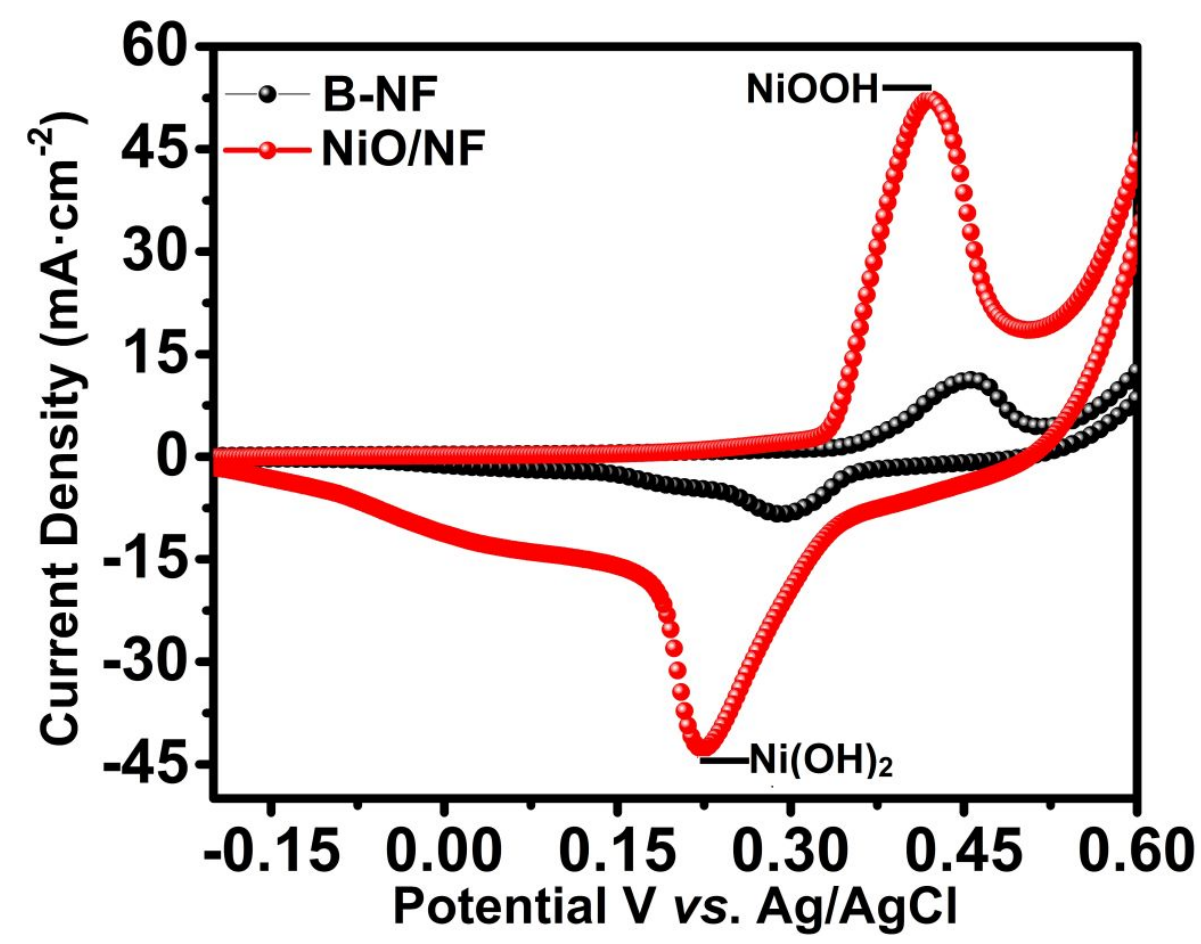

Figure S5. CVs of $\mathrm{B}-\mathrm{NF}$ and $\mathrm{NiO} / \mathrm{NF}$ electrodes in $1 \mathrm{M} \mathrm{KOH}$ at a scan rate of $50 \mathrm{mV} \cdot \mathrm{s}^{-1}$.

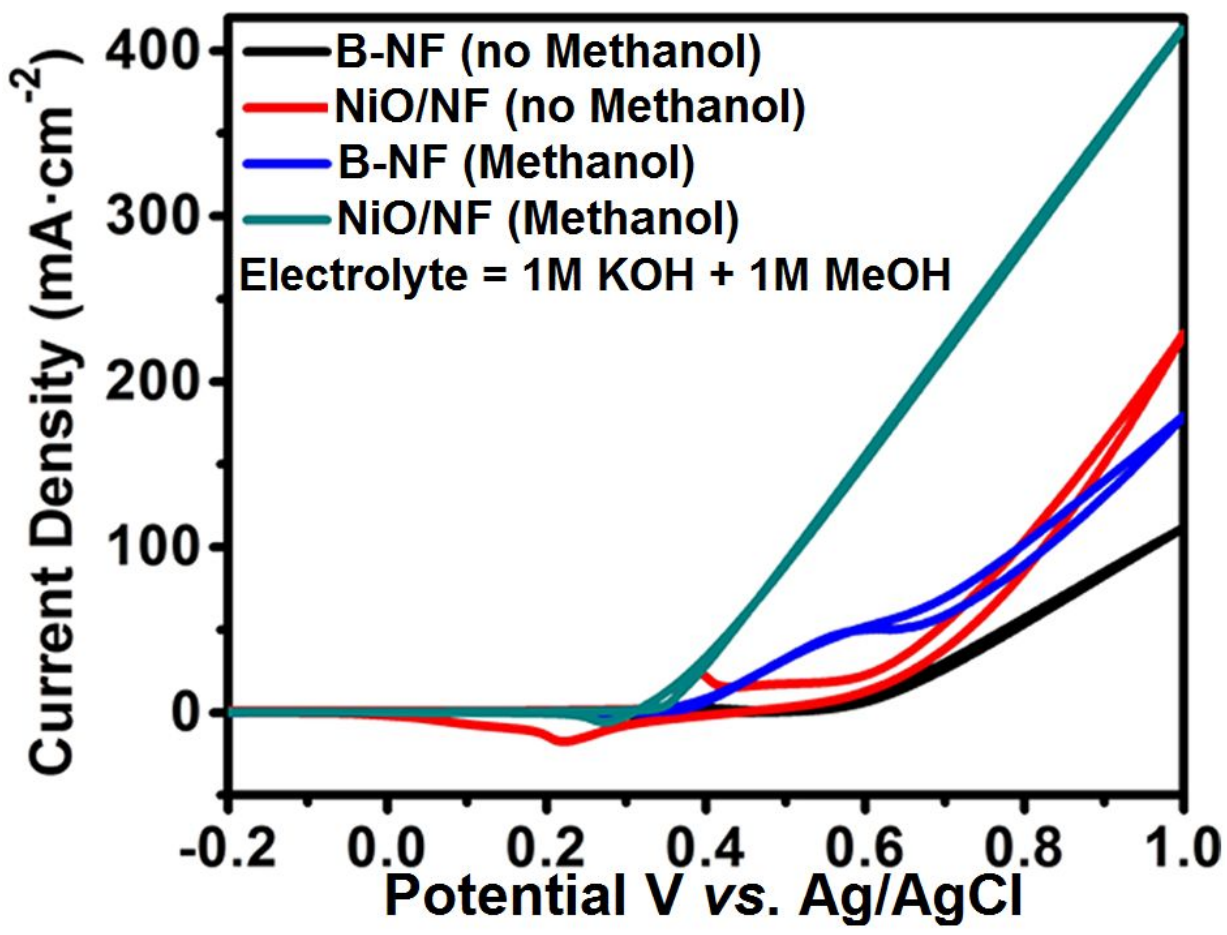

Figure S6. Cyclic voltammograms (CVs) for $\mathrm{B}-\mathrm{NF}$ and $\mathrm{NiO} / \mathrm{NF}$ in presence and absence of 1.0 $\mathrm{M}$ methanol recorded in $1.0 \mathrm{M} \mathrm{KOH}$ at a scan rate of $10 \mathrm{mV} \mathrm{s}^{-1}$. 


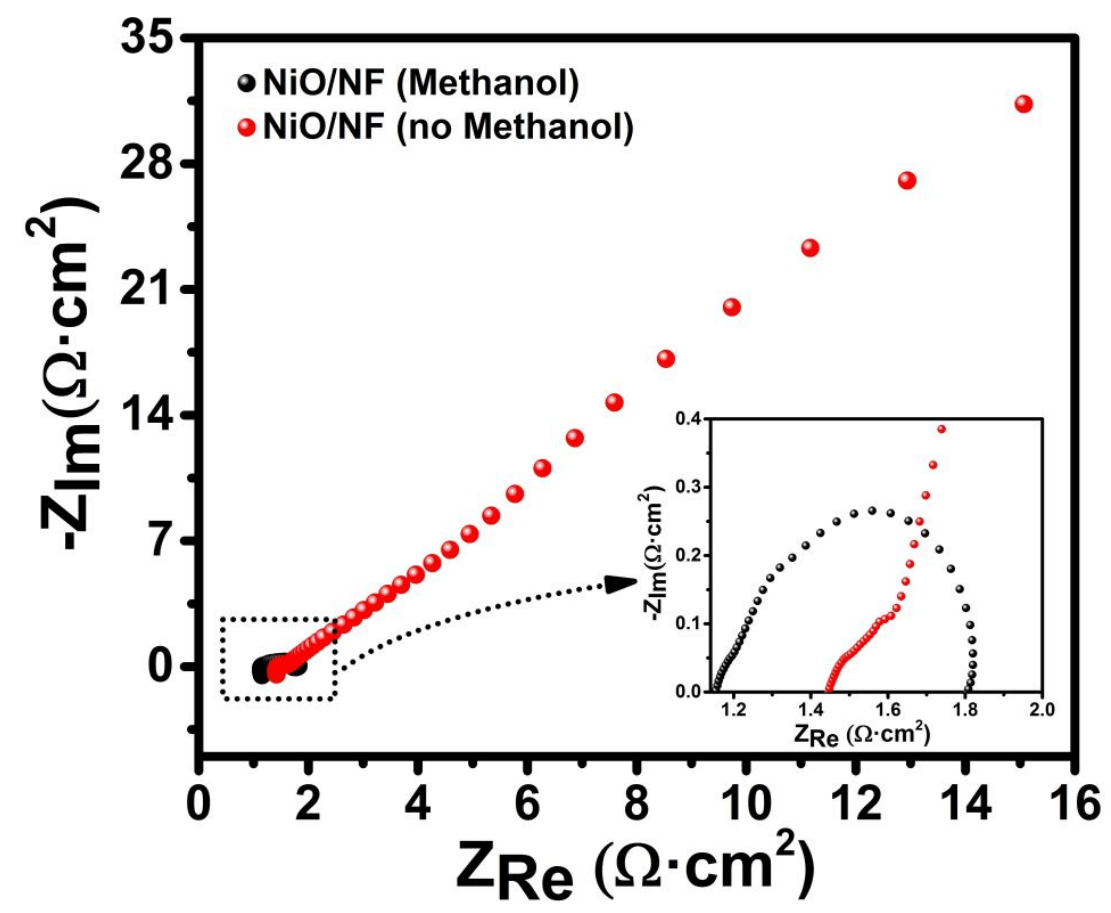

Figure S7. Nyquist plots of $\mathrm{NiO} / \mathrm{NF}$ at $+0.45 \mathrm{~V}$ vs. $\mathrm{Ag} / \mathrm{AgCl}$ with and without $1.0 \mathrm{M}$ methanol in $1.0 \mathrm{M} \mathrm{KOH}$.

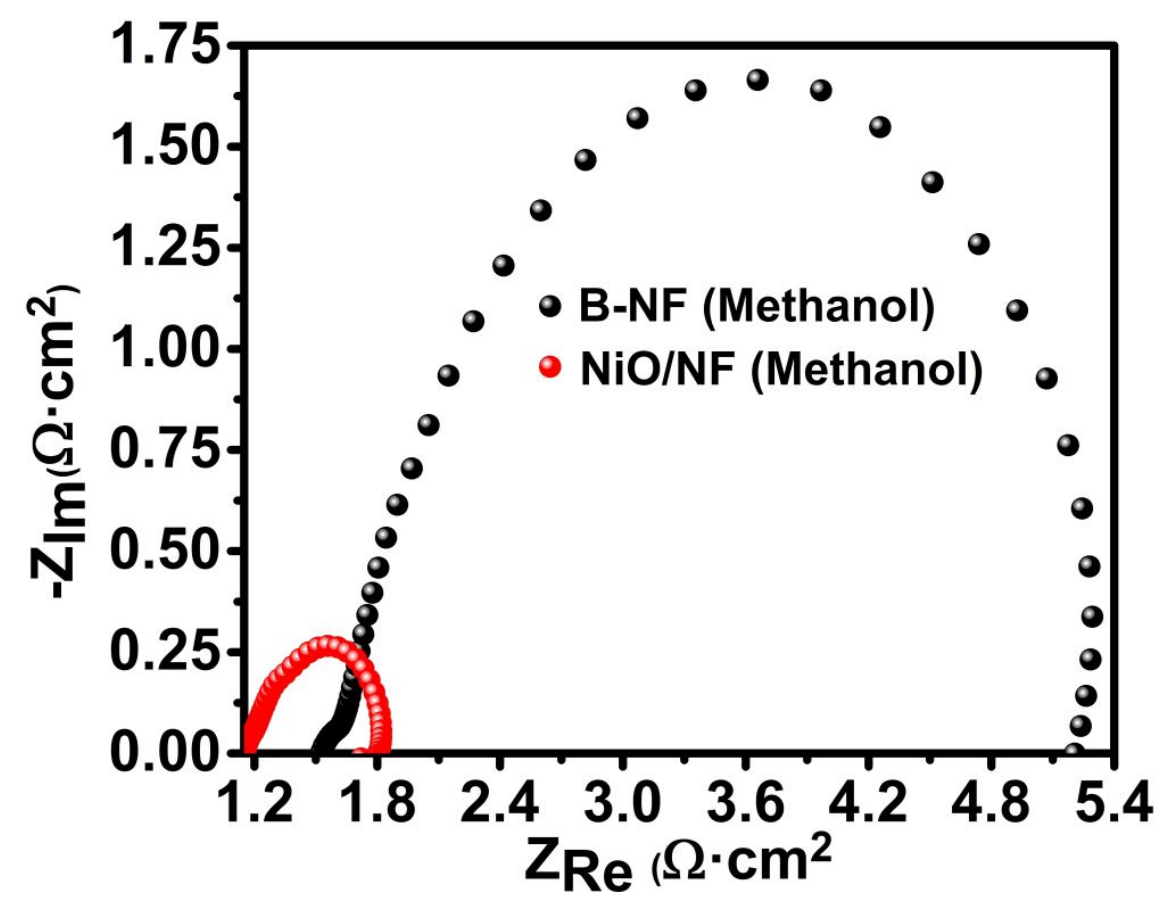

Figure S8. EIS plots of B-NF and NiO/NF in presence of 1.0 M methanol $+1.0 \mathrm{M} \mathrm{KOH}$ 

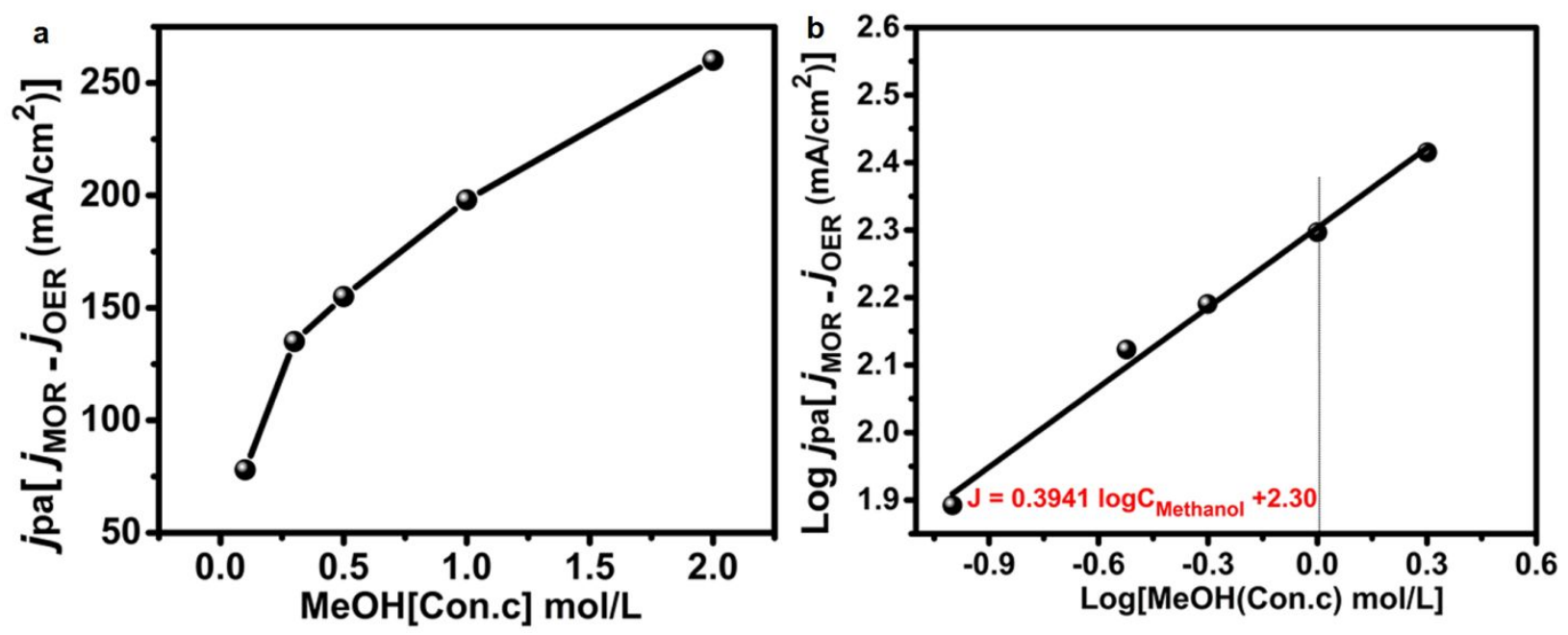

Figure S9. (a) The curve of anodic peak current densities versus concentrations of methanol on $\mathrm{NiO} / \mathrm{NF}$ electrode at $+0.8 \mathrm{~V} v s . \mathrm{Ag} / \mathrm{AgCl}$. (b) Fitting and linear correlation between the anodic peak current densities and methanol concentration.

The slope of the fitting straight line is equal to the order of the MOR as following relations: ${ }^{10}$

$$
\log j=\log k+n \log C
$$

where $j, k, C$ and $n$ are the peak current density, the reaction rate constant, the concentration of methanol and the reaction order. Value of 0.39 and 0.30 was estimated for the order of MOR at $\mathrm{NiO} / \mathrm{NF}$. 


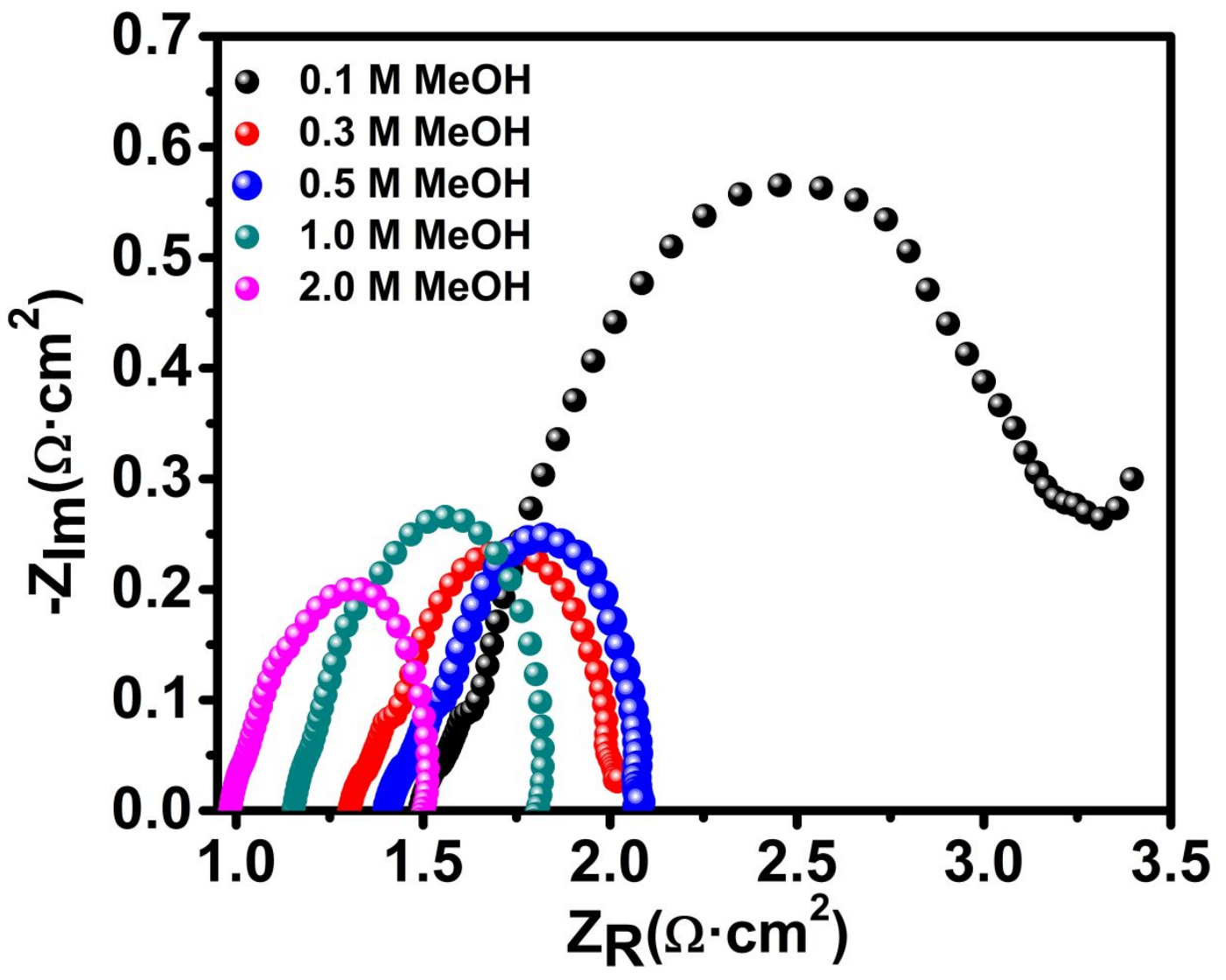

Figure S10. EIS plots of $\mathrm{NiO} / \mathrm{NF}$ in $1.0 \mathrm{M} \mathrm{KOH}$ solution in the presence of methanol at various concentrations $(0.1,0.3,0.5,1.0$ and $2.0 \mathrm{M})$. 


\section{MOR product analysis and proposed mechanism}

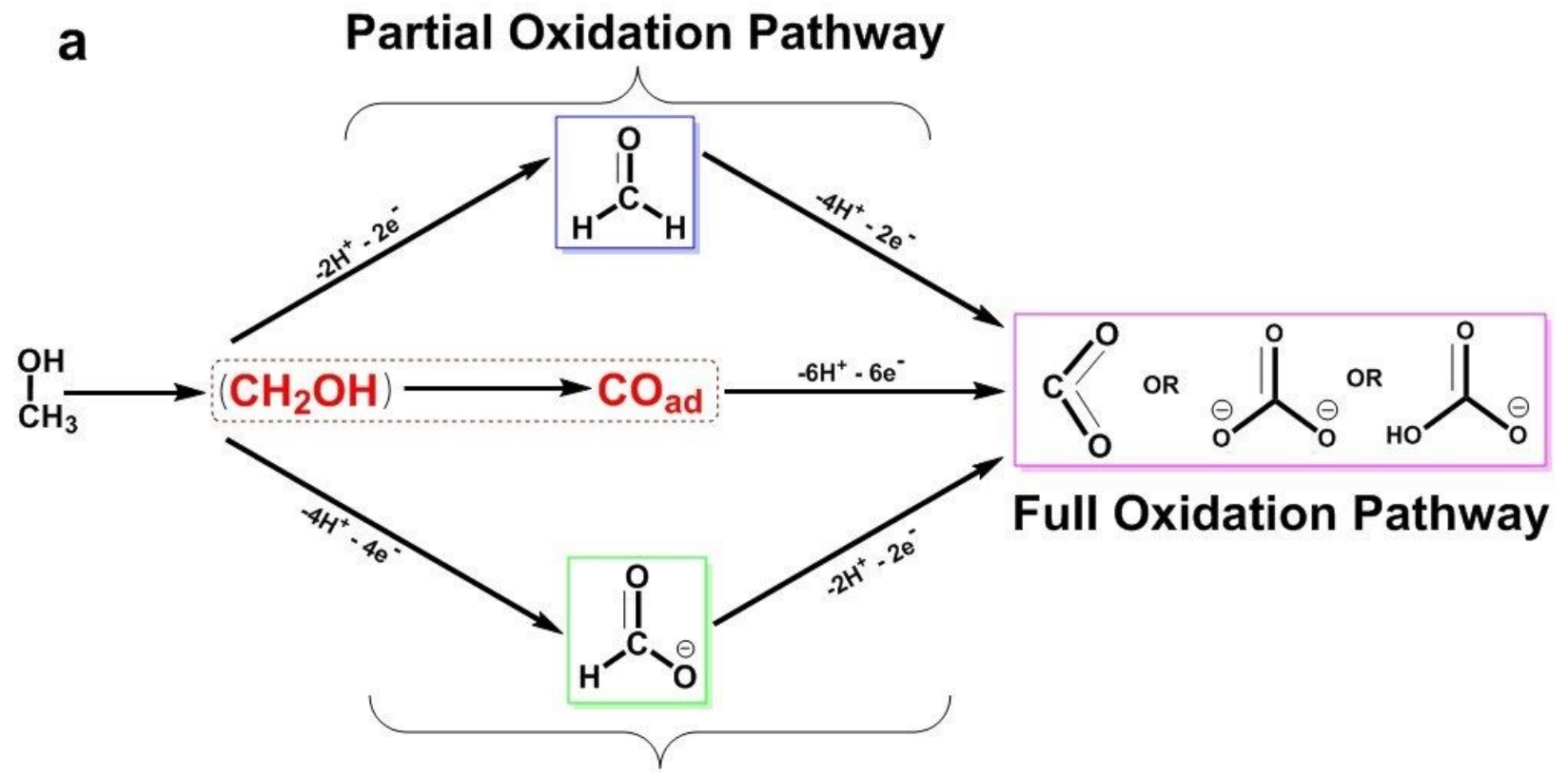

\section{Proposed MOR Mechanism in KOH}
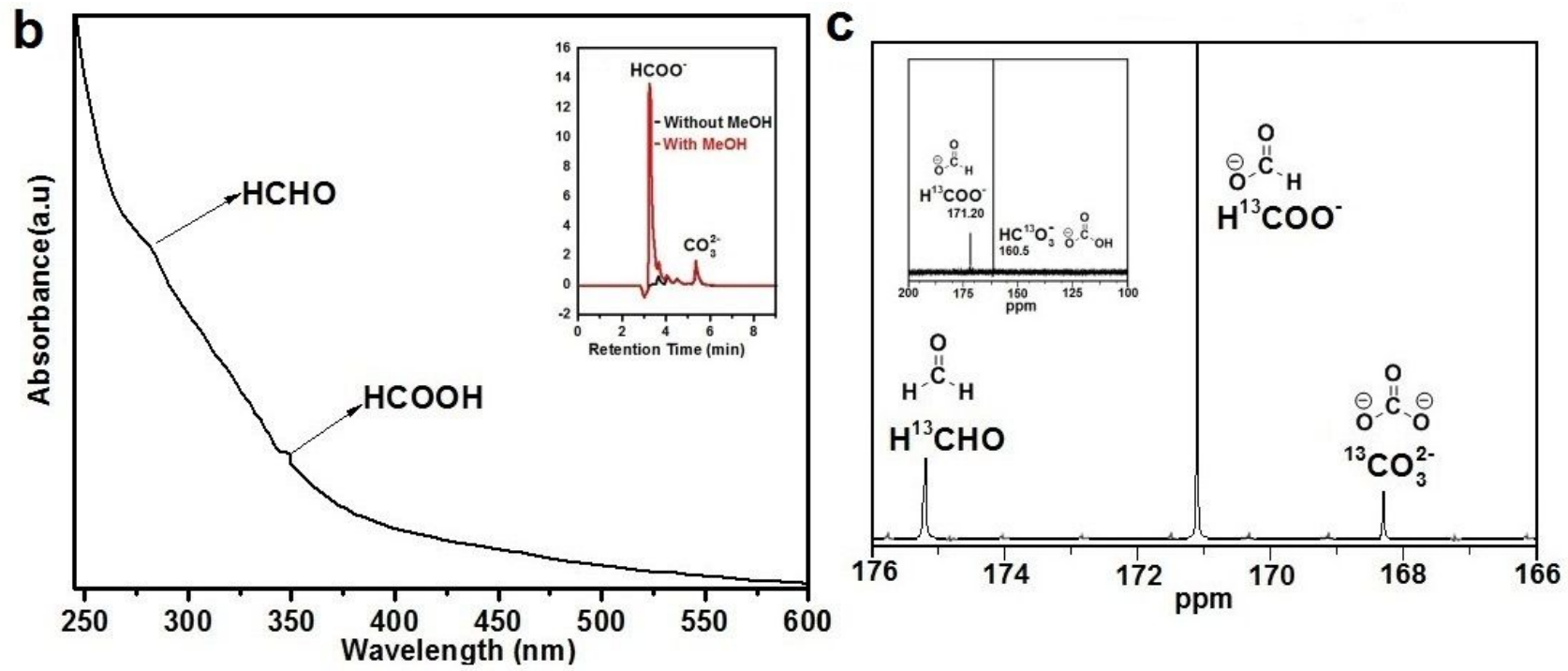

Figure S11. (a) Proposed mechanism of MOR in alkaline electrolyte. (b) Product analysis using $\mathrm{UV}$-Vis spectra after $1.5 \mathrm{~h}$ long time electrochemical test and inset of Figure S11a showed Ion chromatographic spectra of the electrolyte with and without long time electrochemical test that were positioned in same environments for $15 \mathrm{~h}$. (c) ${ }^{13} \mathrm{C}$ NMR spectrum of the electrolyte where 
${ }^{13} \mathrm{CH}_{3} \mathrm{OH}$ was used instead of $\mathrm{CH}_{3} \mathrm{OH}$ after the long time electrochemical test and inset of Figure S11b ${ }^{13} \mathrm{C}$ NMR spectrum of the electrolyte after $15 \mathrm{~h}$ long time electrochemical test.

\begin{tabular}{|c|c|c|c|c|c|c|c|c|c|}
\hline S.N & Catalyst & Morphology & $\begin{array}{c}\text { Onset } \\
\text { potential } \\
\text { V vs. RHE }\end{array}$ & $\begin{array}{c}\text { Current } \\
\text { density } \\
j\left(\mathrm{~mA} \cdot \mathrm{cm}^{-2}\right) \\
\text { aV vs. RHE } \\
\text { geometric } \\
\text { MOR }\end{array}$ & $\begin{array}{c}\text { [a] MOR } I_{\text {ap }} \\
\left(\mathrm{mA} \cdot \mathrm{cm}^{-2}\right) \\
\text { aV vs. RHE }\end{array}$ & 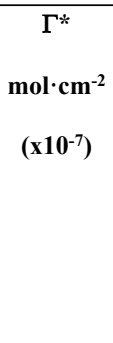 & $\begin{array}{c}D_{\mathrm{H}+} \\
\mathrm{cm}^{2} \cdot \mathrm{s}^{-1} \\
\left(\times 10^{-7}\right)\end{array}$ & Electrolyte & Ref \\
\hline 1 & $\mathrm{Ni}_{2.5} \mathrm{Co}_{0.5} \mathrm{Sn}_{2}$ & NPs & 1.38 & $65.5 @ 1.57$ & - & 1.4 & 0.128 & $1.0 \mathrm{M} \mathrm{MeOH}+1.0 \mathrm{M} \mathrm{KOH}$ & 7 \\
\hline 2 & $\mathrm{Ni}_{3} \mathrm{Sn}_{2}$ & NPs & - & 34.4@1.57 & - & 0.86 & 0.084 & $1.0 \mathrm{M} \mathrm{MeOH}+1.0 \mathrm{M} \mathrm{KOH}$ & \\
\hline 3 & $\mathrm{Ni}_{0.75} \mathrm{Cu}_{0.25}$ & 3D Networks & 1.35 & $160 @ 2.0$ & 84@1.69 & 4.48 & 0.289 & $0.5 \mathrm{M} \mathrm{MeOH}+1.0 \mathrm{M} \mathrm{NaOH}$ & 11 \\
\hline 4 & Ni-NP & NPs & & $35 @ 2.0$ & 12@1.64 & 0.89 & - & $0.5 \mathrm{M} \mathrm{MeOH}+1.0 \mathrm{M} \mathrm{KOH}$ & 12 \\
\hline 5 & NiFe-NP & NPs & 1.40 & $50 @ 1.56$ & - & - & - & $1.0 \mathrm{M} \mathrm{MeOH}+1.0 \mathrm{M} \mathrm{NaOH}$ & 13 \\
\hline 6 & NiO/Ni@CNT & Nanostructure & 1.43 & ２.7@1.82 & 1.5@1.62 & - & - & $1.0 \mathrm{M} \mathrm{MeOH}+1.0 \mathrm{M} \mathrm{KOH}$ & 14 \\
\hline 7 & $\mathrm{Ni}_{2} \mathrm{Co}_{2}$ & Cauliflower & - & $120 @ 2.0$ & ３5@1.74 & 1.63 & - & $0.5 \mathrm{M} \mathrm{MeOH}+1.0 \mathrm{M} \mathrm{NaOH}$ & 15 \\
\hline 8 & $\mathrm{Ni}_{0.5} \mathrm{Co}_{0.5}$ & Porous alloy & - & $120 @ 2.0$ & 35@1.69 & 1.63 & - & $0.5 \mathrm{M} \mathrm{MeOH}+1.0 \mathrm{M} \mathrm{NaOH}$ & 16 \\
\hline 9 & $\mathrm{Ni} / \mathrm{Ti}$ & Falkes & - & $39 @ 1.62$ & - & - & - & $0.5 \mathrm{M} \mathrm{MeOH}+1.0 \mathrm{M} \mathrm{NaOH}$ & 17 \\
\hline
\end{tabular}

\section{Comparison of MOR performance}

Table S1. Comparison of MOR performance between $\mathrm{NiO} / \mathrm{NF}$ and other non-noble catalysts reported in the literature. 


\begin{tabular}{|c|c|c|c|c|c|c|c|c|c|}
\hline 10 & Ni-Ti-NP & NPs & - & $0.65 @ 2.0$ & $0.5 @ 1.62$ & - & - & $0.1 \mathrm{M} \mathrm{NaOH}+0.2 \mathrm{MeOH}$ & 18 \\
\hline 11 & $\mathrm{NiMn}$ & Film & - & 115@2.0 & $80 @ 1.64$ & 0.62 & - & $0.5 \mathrm{M} \mathrm{MeOH}+1.0 \mathrm{M} \mathrm{NaOH}$ & 19 \\
\hline 12 & $\mathrm{Ni}_{1.7} \mathrm{Sn}$ & NPs & 1.41 & $80 @ 2.0$ & $51 @ 1.65$ & 2.1 & 0.00019 & $0.5 \mathrm{M} \mathrm{MeOH}+0.5 \mathrm{M} \mathrm{KOH}$ & 20 \\
\hline 13 & Ni/SBACPE-NP & Mesoporous & - & $23 @ 2.0$ & $14.2 @ 1.8$ & 0.90 & - & $0.03 \mathrm{M} \mathrm{MeOH}+0.1 \mathrm{M} \mathrm{NaOH}$ & 21 \\
\hline 14 & $\mathrm{CuNi}$ & Porous NWs & - & - & $21 @ 1.85$ & - & - & $0.2 \mathrm{M} \mathrm{MeOH}+0.1 \mathrm{M} \mathrm{NaOH}$ & 22 \\
\hline 15 & $\mathrm{NiCo}_{2} \mathrm{O}_{4} / \mathrm{GCE}$ & Nanoflakes & - & 15.5@2.0 & 11@1.67 & - & - & $1.0 \mathrm{M} \mathrm{MeOH}+0.1 \mathrm{M} \mathrm{NaOH}$ & 23 \\
\hline 16 & $\mathrm{Cu} / \mathrm{NiCu}-\mathrm{NW}$ & Nanowires & 1.25 & $34.9 @ 1.55$ & - & 0.026 & - & $1.0 \mathrm{M} \mathrm{MeOH}+1.0 \mathrm{M} \mathrm{KOH}$ & 24 \\
\hline 17 & NiO-NS@NW & Nanowires & - & 89@1.62 & - & - & - & $0.5 \mathrm{M} \mathrm{MeOH}+1.0 \mathrm{M} \mathrm{KOH}$ & 25 \\
\hline 18 & $\mathrm{Ni}_{0.2} \mathrm{Co}_{0.2-\mathrm{G}}$ & NPs & - & $225 @ 2.0$ & - & 3.05 & - & $2.0 \mathrm{M} \mathrm{MeOH}+1.0 \mathrm{M} \mathrm{KOH}$ & 26 \\
\hline 19 & $\mathrm{NiMoO}_{4} / \mathrm{C}$ & Nanorods & - & 49@1.79 & - & & - & $2.0 \mathrm{M} \mathrm{MeOH}+1.0 \mathrm{M} \mathrm{KOH}$ & 27 \\
\hline 20 & Ni-beta-SDS/GC & Zeolite & - & $21 @ 1.76$ & - & - & - & $0.1 \mathrm{M} \mathrm{MeOH}+0.1 \mathrm{M} \mathrm{KOH}$ & 28 \\
\hline 21 & $\mathrm{Ni}_{97} \mathrm{Bi}_{3}$ aerogel & Nanowires & 1.33 & 199@1.66 & - & 3.97 & 2.0 & $1.0 \mathrm{M} \mathrm{MeOH}+1.0 \mathrm{M} \mathrm{KOH}$ & 8 \\
\hline 22 & $\mathrm{NiCo} / \mathrm{NiO}-\mathrm{CoO}$ & Petal-like & 1.34 & 178@1.65 & - & - & - & $0.5 \mathrm{M} \mathrm{MeOH}+0.5 \mathrm{M} \mathrm{KOH}$ & 1 \\
\hline 23 & $\mathrm{NiO}-\mathrm{NS}$ & Nanosheets & 1.37 & $85.3 @ 1.72$ & & - & - & $0.5 \mathrm{M} \mathrm{MeOH}+1.0 \mathrm{M} \mathrm{KOH}$ & 29 \\
\hline 24 & $\mathrm{Mn}-\mathrm{Ni}(\mathrm{OH})_{2}$ & Hollow & 1.35 & $23 @ 2.0$ & 16.7@1.6 & - & - & $0.5 \mathrm{M} \mathrm{MeOH}+1.0 \mathrm{M} \mathrm{KOH}$ & 30 \\
\hline 25 & NiO-NTs-400 & Nanotubes & 1.33 & $24.3 @ 1.50$ & - & 3.75 & - & $0.5 \mathrm{M} \mathrm{MeOH}+1.0 \mathrm{M} \mathrm{NaOH}$ & 31 \\
\hline 26 & KB\&CTGU-15 & MOFs & 1.43 & 29.8@1.62 & - & - & & $1.0 \mathrm{M} \mathrm{MeOH}+0.1 \mathrm{M} \mathrm{KOH}$ & 32 \\
\hline 28 & $\mathrm{Cu} @ \mathrm{CoO}_{\mathrm{x}}$ & Core-cage & 1.33 & 300@1.87 & 150@1.88 & - & - & $1.0 \mathrm{M} \mathrm{MeOH}+1.0 \mathrm{M} \mathrm{NaOH}$ & 33 \\
\hline 29 & $\mathrm{CuO} / \mathrm{Co}(\mathrm{OH})_{2}$ & Nanosheets & 1.35 & - & 159@1.65 & - & - & $3.0 \mathrm{M} \mathrm{MeOH}+1.0 \mathrm{M} \mathrm{NaOH}$ & 34 \\
\hline 30 & $\mathrm{NiCoP}$ & Hollow & - & 155@1.7 & - & - & - & $1.0 \mathrm{M} \mathrm{MeOH}+1.0 \mathrm{M} \mathrm{KOH}$ & 9 \\
\hline 31 & $\mathrm{NiO} @ \mathrm{C} / \mathrm{CC}$ & Nanoparticles & 1.51 & 188@2.01 & - & - & - & $1.0 \mathrm{M} \mathrm{MeOH}+1.0 \mathrm{M} \mathrm{KOH}$ & 35 \\
\hline 32 & Branched $\mathrm{Ni}_{3} \mathrm{C}$ & Branched & 1.43 & 126.7@1.64 & - & 1.93 & 0.002 & $1.0 \mathrm{M} \mathrm{MeOH}+1.0 \mathrm{M} \mathrm{KOH}$ & 6 \\
\hline \multirow[t]{9}{*}{33} & \multirow[t]{9}{*}{$\mathrm{NiO} / \mathrm{NF}$} & \multirow[t]{9}{*}{ Nanosheets array } & \multirow[t]{9}{*}{1.34} & 100@1.70 & \multirow[t]{2}{*}{ 78@1.80 } & \multirow[t]{9}{*}{6.33} & \multirow[t]{9}{*}{4.5} & \multirow[t]{2}{*}{$0.1 \mathrm{M} \mathrm{MeOH}+1.0 \mathrm{M} \mathrm{KOH}$} & \multirow{9}{*}{\begin{tabular}{|l} 
This \\
Work
\end{tabular}} \\
\hline & & & & 200@1.87 & & & & & \\
\hline & & & & 100@1.58 & \multirow[t]{2}{*}{ 135@1.81 } & & & \multirow[t]{2}{*}{$0.3 \mathrm{M} \mathrm{MeOH}+1.0 \mathrm{M} \mathrm{KOH}$} & \\
\hline & & & & $200 @ 1.75$ & & & & & \\
\hline & & & & 100@1.56 & \multirow[t]{2}{*}{ 155@1.81 } & & & \multirow{2}{*}{$0.5 \mathrm{M} \mathrm{MeOH}+1.0 \mathrm{M} \mathrm{KOH}$} & \\
\hline & & & & $200 @ 1.73$ & & & & & \\
\hline & & & & 100@1.53 & \multirow[t]{3}{*}{ 198@1.85 } & & & \multirow[t]{3}{*}{$1.0 \mathrm{M} \mathrm{MeOH}+1.0 \mathrm{M} \mathrm{KOH}$} & \\
\hline & & & & 200@1.68 & & & & & \\
\hline & & & & $300 @ 1.84$ & & & & & \\
\hline
\end{tabular}




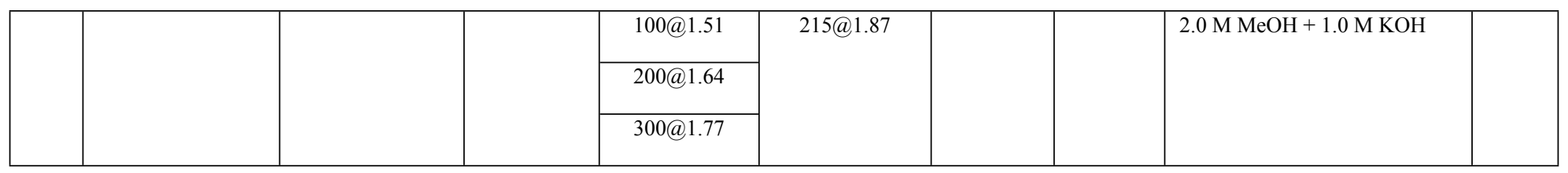

[a] Calculated values by subtracting the corresponding baseline current obtained in the absence

of methanol.

Note: *For comparison, the on-set potential and applied potential was intended to convert to be vs. RHE using the equation:

$$
E_{\mathrm{RHE}}=E_{\mathrm{Ref}}^{0}+E_{\mathrm{Ref}}+0.059 \times \mathrm{pH}
$$

Where $E^{0}$ Ref is potential of the reference, $E_{\text {Ref }}$ is the potential that measured vs. reference; $\mathrm{pH}$ is simply converted from the alkaline electrolyte.

\section{References}

(1) Rezaee, S.; Shahrokhian, S. Facile synthesis of petal-like NiCo/NiO-CoO/nanoporous carbon composite based on mixed-metallic MOFs and their application for electrocatalytic oxidation of methanol. Appl. Catal. B Environ. 2019, 244, 802-813.

(2) Bard, A. J.; Faulkner, L. R. Fundamentals and applications. Electrochem. Methods 2001, 2, 482.

(3) Dubale, A. A.; Zheng, Y.; Wang, H.; Hübner, R.; Li, Y.; Yang, J.; Zhang, J.; Sethi, N. K.; He, L.; Zheng, Z. High-performance Bismuth doped Nickel Aerogel Electrocatalyst for Methanol Oxidation Reaction. Angew. Chem. Int. Ed. 2020, 59 (33), 13891-13899.

(4) Li, J.; Luo, Z.; Zuo, Y.; Liu, J.; Zhang, T.; Tang, P.; Arbiol, J.; Llorca, J.; Cabot, A. NiSn bimetallic nanoparticles as stable electrocatalysts for methanol oxidation reaction. Appl. Catal. B 2018, 234, 10-18, DOI: https://doi.org/10.1016/j.apcatb.2018.04.017.

(5) Li, J.; Zuo, Y.; Liu, J.; Wang, X.; Yu, X.; Du, R.; Zhang, T.; Infante-Carrió, M. F.; Tang, P.; Arbiol, J. Superior methanol electrooxidation performance of (110)-faceted nickel polyhedral nanocrystals. J. Mater. Chem. A 2019, 7 (38), 22036-22043.

(6) Li, J.; Wei, R.; Wang, X.; Zuo, Y.; Han, X.; Arbiol, J.; Llorca, J.; Yang, Y.; Cabot, A.; Cui, C. Selective Methanol-to-Formate Electrocatalytic Conversion on Branched Nickel Carbide. Angew. Chem. Int. Ed. 2020, 59 (47), 20826-20830, DOI: https://doi.org/10.1002/anie.202004301. 
(7) Li, J.; Luo, Z.; He, F.; Zuo, Y.; Zhang, C.; Liu, J.; Yu, X.; Du, R.; Zhang, T.; InfanteCarrió, M. F.; Tang, P.; Arbiol, J.; Llorca, J.; Cabot, A. Colloidal Ni-Co-Sn nanoparticles as efficient electrocatalysts for the methanol oxidation reaction. J. Mater. Chem. A 2018, 6 (45), 22915-22924, DOI: 10.1039/C8TA08242A.

(8) Dubale, A. A.; Zheng, Y.; Wang, H.; Hübner, R.; Li, Y.; Yang, J.; Zhang, J.; Sethi, N. K.; He, L.; Zheng, Z. High-performance Bismuth-doped Nickel Aerogel Electrocatalyst for Methanol Oxidation Reaction. Angew. Chem. Int. Ed. 2020.

(9) Chen, S.; Yang, X.; Tong, X.; Zhang, F.; Zou, H.; Qiao, Y.; Dong, M.; Wang, J.; Fan, W. Design of 3D Hollow Porous Heterogeneous Nickel-Cobalt Phosphides for Synergistically Enhancing Catalytic Performance for Electrooxidation of Methanol. ACS Appl. Mater. Interfaces 2020, 12 (31), 34971-34979, DOI: 10.1021/acsami.0c08912.

(10) Hameed, R. A.; El-Sherif, R. M. Microwave irradiated nickel nanoparticles on Vulcan XC72R carbon black for methanol oxidation reaction in $\mathrm{KOH}$ solution. Appl. Catal. B-Environ 2015, 162, 217-226.

(11) Cui, X.; Xiao, P.; Wang, J.; Zhou, M.; Guo, W.; Yang, Y.; He, Y.; Wang, Z.; Yang, Y.; Zhang, Y.; Lin, Z. Highly Branched Metal Alloy Networks with Superior Activities for the Methanol Oxidation Reaction. Angew. Chem. Int. Ed. 2017, 56 (16), 4488-4493, DOI: 10.1002/anie.201701149.

(12) Abdel Hameed, R. M.; El-Sherif, R. M. Microwave irradiated nickel nanoparticles on Vulcan XC-72R carbon black for methanol oxidation reaction in $\mathrm{KOH}$ solution. Appl. Catal. B Environ. 2015, 162, 217-226, DOI: https://doi.org/10.1016/j.apcatb.2014.06.057.

(13) Candelaria, S. L.; Bedford, N. M.; Woehl, T. J.; Rentz, N. S.; Showalter, A. R.; Pylypenko, S.; Bunker, B. A.; Lee, S.; Reinhart, B.; Ren, Y.; Ertem, S. P.; Coughlin, E. B.; Sather, N. A.; Horan, J. L.; Herring, A. M.; Greenlee, L. F. Multi-Component Fe-Ni Hydroxide Nanocatalyst for Oxygen Evolution and Methanol Oxidation Reactions under Alkaline Conditions. ACS Catal. 2017, 7 (1), 365-379, DOI: 10.1021/acscatal.6b02552.

(14) Wang, J.; Teschner, D.; Yao, Y.; Huang, X.; Willinger, M.; Shao, L.; Schlögl, R. Fabrication of nanoscale $\mathrm{NiO} / \mathrm{Ni}$ heterostructures as electrocatalysts for efficient methanol oxidation. J. Mater. Chem. A 2017, 5 (20), 9946-9951, DOI: 10.1039/C7TA01982C.

(15) Cui, X.; Guo, W.; Zhou, M.; Yang, Y.; Li, Y.; Xiao, P.; Zhang, Y.; Zhang, X. Promoting Effect of Co in NimCon $(\mathrm{m}+\mathrm{n}=4)$ Bimetallic Electrocatalysts for Methanol Oxidation Reaction. ACS Appl. Mater. Interfaces 2015, 7 (1), 493-503, DOI: 10.1021/am506554b.

(16) X. Cui, Y. Y., Y. Li, F. Liu, H. Peng, Y. Zhang and P. Xiao. J. Electrochem. Soc 2015, 162, F1415-F1424.

(17) Yi, Q.; Huang, W.; Zhang, J.; Liu, X.; Li, L. Methanol oxidation on titanium-supported nano-scale Ni flakes. Catal. Commun. 2008, 9 (10), 2053-2058, DOI:

https://doi.org/10.1016/j.catcom.2008.03.051.

(18) Yu, Y.; Yang, Q.; Li, X.; Guo, M.; Hu, J. A bimetallic Ni-Ti nanoparticle modified indium tin oxide electrode fabricated by the ion implantation method for studying the direct electrocatalytic oxidation of methanol. Green Chem. 2016, 18 (9), 2827-2833, DOI: 10.1039/C5GC02551F.

(19) Danaee, I.; Jafarian, M.; Mirzapoor, A.; Gobal, F.; Mahjani, M. Electrooxidation of methanol on NiMn alloy modified graphite electrode. Electrochim. Acta 2010, 55 (6), 20932100 . 
(20) Li, J.; Luo, Z.; Zuo, Y.; Liu, J.; Zhang, T.; Tang, P.; Arbiol, J.; Llorca, J.; Cabot, A. NiSn bimetallic nanoparticles as stable electrocatalysts for methanol oxidation reaction. Appl. Catal. B Environ 2018, 234, 10-18, DOI: https://doi.org/10.1016/j.apcatb.2018.04.017.

(21) Azizi, S. N.; Ghasemi, S.; Chiani, E. Nickel/mesoporous silica (SBA-15) modified electrode: An effective porous material for electrooxidation of methanol. Electrochim. Acta 2013, 88, 463-472, DOI: https://doi.org/10.1016/j.electacta.2012.10.032.

(22) Ding, R.; Liu, J.; Jiang, J.; Wu, F.; Zhu, J.; Huang, X. Tailored Ni-Cu alloy hierarchical porous nanowire as a potential efficient catalyst for DMFCs. Catal. Sci. Technol. 2011, 1 (8), 1406-1411, DOI: 10.1039/C1CY00164G.

(23) Anu Prathap, M. U.; Srivastava, R. Synthesis of NiCo2O4 and its application in the electrocatalytic oxidation of methanol. Nano Energy 2013, 2 (5), 1046-1053, DOI:

https://doi.org/10.1016/j.nanoen.2013.04.003.

(24) Wu, D.; Zhang, W.; Cheng, D. Facile Synthesis of Cu/NiCu Electrocatalysts Integrating Alloy, Core-Shell, and One-Dimensional Structures for Efficient Methanol Oxidation Reaction. ACS Appl. Mater. Interfaces 2017, 9 (23), 19843-19851, DOI: 10.1021/acsami.7b03876.

(25) Luo, Q.; Peng, M.; Sun, X.; Asiri, A. M. Hierarchical nickel oxide nanosheet@nanowire arrays on nickel foam: an efficient 3D electrode for methanol electro-oxidation. Catal. Sci. Technol. 2016, 6 (4), 1157-1161, DOI: 10.1039/C5CY01427A.

(26) Barakat, N. A. M.; Motlak, M. CoxNiy-decorated graphene as novel, stable and super effective non-precious electro-catalyst for methanol oxidation. Appl. Catal. B Environ 2014, 154-155, 221-231, DOI: https://doi.org/10.1016/j.apcatb.2014.02.019.

(27) Jothi, P. R.; Kannan, S.; G, V. Enhanced methanol electro-oxidation over in-situ carbon and graphene supported one dimensional NiMoO4 nanorods. J. Power Sources 2015, 277, 350359, DOI: https://doi.org/10.1016/j.jpowsour.2014.11.137.

(28) Liao, Y.; Pan, S.; Bian, C.; Meng, X.; Xiao, F.-S. Improved catalytic activity in methanol electro-oxidation over the nickel form of aluminum-rich beta-SDS zeolite modified electrode. $J$. Mater. Chem. A 2015, 3 (11), 5811-5814, DOI: 10.1039/C4TA06699E.

(29) Yang, W.; Yang, X.; Jia, J.; Hou, C.; Gao, H.; Mao, Y.; Wang, C.; Lin, J.; Luo, X. Oxygen vacancies confined in ultrathin nickel oxide nanosheets for enhanced electrocatalytic methanol oxidation. Appl. Catal. B Environ. 2019, 244, 1096-1102.

(30) Dong, B.; Li, W.; Huang, X.; Ali, Z.; Zhang, T.; Yang, Z.; Hou, Y. Fabrication of hierarchical hollow Mn doped $\mathrm{Ni}(\mathrm{OH}) 2$ nanostructures with enhanced catalytic activity towards electrochemical oxidation of methanol. Nano Energy 2019, 55, 37-41.

(31) Wang, T.-J.; Huang, H.; Wu, X.-R.; Yao, H.-C.; Li, F.-M.; Chen, P.; Jin, P.-J.; Deng, Z.W.; Chen, Y. Self-template synthesis of defect-rich NiO nanotubes as efficient electrocatalysts for methanol oxidation reaction. Nanoscale 2019, 11 (42), 19783-19790.

(32) Wu, Y. P.; Tian, J. W.; Liu, S.; Li, B.; Zhao, J.; Ma, L. F.; Li, D. S.; Lan, Y. Q.; Bu, X. BiMicroporous Metal-Organic Frameworks with Cubane [M4 (OH) 4](M=Ni, Co) Clusters and Pore-Space Partition for Electrocatalytic Methanol Oxidation Reaction. Angew. Chem. 2019, 131 (35), 12313-12317.

(33) Sun, Y.; Zhou, Y.; Zhu, C.; Tu, W.; Wang, H.; Huang, H.; Liu, Y.; Shao, M.; Zhong, J.; Lee, S.-T. Synergistic $\mathrm{Cu} @ \mathrm{CoOx}$ core-cage structure on carbon layers as highly active and durable electrocatalysts for methanol oxidation. Appl. Catal. B Environ. 2019, 244, 795-801.

(34) Chen, L.; Hua, Z.; Shi, J.; He, M. CuO/Co (OH) 2 nanosheets: a novel kind of electrocatalyst for highly efficient electrochemical oxidation of methanol. ACS Appl. Mater. interfaces 2018, 10 (45), 39002-39008. 
(35) Liu, C.; Zhou, W.; Zhang, J.; Chen, Z.; Liu, S.; Zhang, Y.; Yang, J.; Xu, L.; Hu, W.; Chen, Y.; Deng, Y. Air-Assisted Transient Synthesis of Metastable Nickel Oxide Boosting Alkaline Fuel Oxidation Reaction. Adv. Energy Mater. 2020, $n / a$ (n/a), 2001397, DOI:

https://doi.org/10.1002/aenm.202001397. 